\title{
Diversity and growth-effects of ectomycorrhizal fungi of a Nothofagus pumilio forest in the Andes of Southern Chile
}

\author{
(Diversidad y efectos de crecimiento de hongos ectomicorrizicos en un \\ bosque de Nothofagus pumilio en los andes del sur de Chile)
}

\begin{abstract}
Cesar Marín ${ }^{1 *}$, Eduardo Valenzuela², Roberto Godoy, Götz Palfner³
${ }^{1}$ Instituto de Ciencias Ambientales y Evolutivas,Universidad Austral de Chile, Valdivia, Chile. ${ }^{2}$ Instituto de Bioquímica y Microbiología, Universidad Austral de Chile, Valdivia, Chile.

${ }^{3}$ Departamento de Botánica, Universidad de Concepción, Concepción, Chile.

* Corresponding Author: cesar.marin@postgrado.uach.cl
\end{abstract}

RECIBIDO: 28 de Abril de 2018

APROBADO: 22 de Mayo de 2018

DOI: 10.22370/bolmicol.2018.33.1.1164

LOS AUTORES DECLARAN NO TENER CONFLICTO DE INTERESES

Key words: Cortinarius, ectomycorrhizal fungi, inoculation experiments, mycotrophic status, temperate rainforests.

Palabras claves: bosques templados lluviosos, Cortinarius, experimentos de inoculación, estatus micotrófico hongos ectomicorrízicos.

\begin{abstract}
Chilean temperate rainforests have unique climatic, edaphic and biotic conditions, constituting pre-industrial blueprint ecosystems. Mycorrhizal associations play a central role in the biogeochemical processes of these ecosystems' functioning. Baseline forest ecology studies are necessary in order to better understand diversity patterns, specifically regarding mycorrhizal symbiosis. Therefore, here we describe the vegetation characteristics and the mycorrhizal relationships of vascular plants in a Nothofagus pumilio forest. We also describe, via morphological methods, the ectomycorrhizal diversity present in this forest. Additionally, we determined whether ectomycorrhizal inoculation confers positive growth effects
\end{abstract}

on $N$. pumilio seedlings. We found that from 46 vascular plant species identified in this study, 42 (91\%) were mycorrhizal and of these 33 (72\%) were associated with arbuscular mycorrhizae (AM), two (the dominant trees $N$. pumilio and $N$. dombeyi) were forming ectomycorrhizae (EM), five were associated with ericoid mycorrhizae, two with orchid mycorrhizae, and four were nonmycorrhizal. Additionally, 26 EM species were detected of which 15 belong to Cortinarius. Finally, there were clear differences in the growth of $N$. pumilio seedlings inoculated with the ectomycorrhizal fungus Laccaria laccata compared to noninoculated plants. We suggest that mycorrhizal fungi play a key role in seedling colonization of harsh environments such as the Andean treeline. 


\section{RESUMEN}

Los bosques templados lluviosos de Chile tienen condiciones climáticas, edáficas y bióticas únicas, constituyendo ecosistemas preindustriales modelo. Las asociaciones micorrízicas juegan un rol central en los procesos biogeoquímicos del funcionamiento de estos ecosistemas. Por lo tanto, en este estudio describimos las características de la vegetación y las relaciones micorrízicas de las plantas vasculares de un bosque de Nothofagus pumilio. También describimos, vía métodos morfológicos, la diversidad ectomicorrízica presente en este bosque. Adicionalmente, determinamos si inoculaciones ectomicorrízicas confieren efectos de crecimiento positivos a semilleros de N. pumilio. Encontramos que, de 46 especies de plantas vasculares identificadas en este estudio, 42 (91\%) son micorrízicas, y de estas, 33 (72\%) están formando micorrizas arbusculares (AM), dos (los árboles dominantes $N$. pumilio y $N$. dombe$y i)$ están asociados con ectomicorrizas (EM), cinco están asociadas con micorrizas ericoides, dos con micorrizas orquioides, y cuatro fueron nomicorrizadas. Adicionalmente, 26 especies de EM fueron detectadas, de las cuales 15 pertenecen a Cortinarius. Finalmente, hubo claras diferencias en el crecimiento de los semilleros de $N$. pumilio inoculados con el hongo ectomicorrízico Laccaria laccata, comparados a plantas no inoculadas. Sugerimos que los hongos micorrízicos juegan un rol clave en la colonización de ambientes severos por juveniles, como en el límite altitudinal andino.

\section{INTRODUCTION}

Southern Chile Nothofagus spp. forests, which extend from central Chile to Tierra del Fuego, present solely ectomycorrhizal (EM) associations as fungal partners. While Nothofagaceae forests exclusively form EM associations, being the only native ectomycorrhizal trees in Andean $\mathrm{Pa}$ tagonian forests ${ }^{1,2,3,4,5,6,7}$ and have a high diversity of agaricoides, Valdivian and native coniferous forests are largely dominated by arbuscular mycorrhizae (AM) ${ }^{8,9,10,11,12,13,14,15}$. In EM or AM dominated forests, the reciprocal mycorrhizal types (either EM or AM, respectively) are not excluded, as they are often associated with understory plants. The dominant genus of EM fungi in Southern South American Nothofagus forests is Cortinarius with at least 200 species described to date ${ }^{16,17}$. Boletales and Russulales, which contribute to an important share of the fungal diversity in northern hemisphere ectotrophic forests, are scarce in Southern South America ${ }^{18,19}$. Nothofagus pumilio forests are usually located at the vegetation limit of the mountain region with a latitudinal extension that covers more than 2,000 km of distribution of this particular forest type at the treeline of the Andes Mountains ${ }^{20}$.

We aimed at (i) determine the vegetation pattern and the mycotrophic status of the vascular plants, and (ii) determine the EM fungal species present in a Nothofagus pumilio forest located at the treeline of Puyehue National Park, Chile $\left(40^{\circ} \mathrm{S}\right)$. Also, we hypothesized that a native ectomycorrhizal species fosters the growth of $\mathrm{No}$ thofagus pumilio (a dominant and test species). To test this, we (iii) measured the effects EM fungal inoculations on $N$. pumilio seedlings.

\section{MATERIALS AND METHODS}

\section{Study plot.}

We selected one $30 \mathrm{~m} \times 30 \mathrm{~m}$ plot in the Andes Mountains of Southern Chile in Puyehue National Park ( $\left.40^{\circ} 47^{\prime} \mathrm{S}-72^{\circ} 12^{\prime} \mathrm{W}\right)$, Antillanca sector (near Raihuen Crater). The plot was located within the altitudinal limit $(1,150-1,200$ m.a.s.l.) of a pristine, deciduous temperate forest of Nothofagus pumilio. The plot receives more than $7,000 \mathrm{~mm}$ of annual precipitation, mostly during winter (June to September), and the annual mean temperature is $4.5^{\circ} \mathrm{C}^{21}$. 
Vegetation patterns and mycorrhizal status.

A previous study has shown that the crown cover of this forest is $95 \%$, and trees of this forest have a medium height of $15 \mathrm{~m}$, a maximum height of 20 $\mathrm{m}$, and an approximate age of 155 years $^{22}$. Dasometric records indicate that the density of trees in the forest is 756 trees ha-1 with an average $\mathrm{DBH}$ of $13.3 \mathrm{~cm}$ and a basal area of $66.6 \mathrm{~m}^{2} \mathrm{ha}^{-1} 22$. The floristic composition of the vascular plants in the plot was determined according to Marticorena \& Quezada (1985) ${ }^{23}$, and life forms were determined according to Ellenberg \& Mueller-Dombois $(1966)^{24}$. In order to determine the types of mycorrhizal associations, fine root samples of at least five individuals of each species were extracted from soil close to the respective plant species, verifying the root attachment, transported to the laboratory, fixed in $70 \%$ alcohol, stained and observed under a microscope for fungal colonization ${ }^{25}$. For determining ectomycorrhizal associations, root samples were observed and described according to Agerer (1995) $)^{26}$ and Palfner (2001) .

\section{Determination of ectomycorrhizal fungal spe- cies.}

The EM fungal species determination was carried out in the whole plot during periodic visits (every two months) for a period of three consecutive years. Fruiting bodies of EM fungi were collected according to Agerer (1991) ${ }^{27}$ and fresh state morpho-anatomic identification was conducted ${ }^{26,27,28}$. Following identification, the fruiting bodies were dried and added to a reference collection. Taxonomic references of Garrido (1988) ${ }^{1}$, Valenzuela et al. (1999) ${ }^{4}$, and Gamundi \& Horak (1993) ${ }^{29}$ were consulted for species determination of gasteroid and agaricoid basidiomycetes, as well as ascomycetes.

Inoculation experiment with Nothofagus pumilio seedlings and ectomycorrhizal fungi.

Nothofagus pumilio seeds were collected in the plot and selected for subsequent stratification at $4^{\circ} \mathrm{C}$. $\mathrm{NaCl}(0.1 \%)$ was applied for $30 \mathrm{~s}$ to aid germination, and then a treatment with gibberellic acid was applied for $24 \mathrm{~h}$, in order to break the endogenic latency. To ensure that the inoculation species would be compatible with the seeds collected, the EM fungal species Laccaria laccata (Scop.) Berk. was collected in the plot, transported to the laboratory, the fungus was isolated from sporocarps, the mycelium grown in several petri dishes with malt Agar $(2 \%)$ at $25^{\circ} \mathrm{C}$. Following this, the fungi were cultured at $25^{\circ} \mathrm{C}$ in $1 \mathrm{~L}$ sterile recipients containing peat:vermiculite $(2: 1)$ substrate and modified Melin-Norkrans (MNM) medium ( $\mathrm{pH}$ 5.0). Cultures were maintained until visible development of the mycelium's vegetative growth $^{30}$. There were three treatments: a control with natural soil and no inoculum, natural soil (from the forest plot) with inoculum, and sterile soil (from the forest plot, sterilized with an autoclave at $121^{\circ} \mathrm{C}, 1 \mathrm{~atm}$, for 30 minutes) with inoculum. Sterile and pre-germinated seedlings (one seedling per pot, 20 pots per treatment, in culture chambers) were selected for uniform height and a $3 \mathrm{~cm}$ radicle; selected seedlings were then planted in $1 \mathrm{~L}$ pots with natural and sterile soil.

A 50 milliliters volume of L. laccata inoculum solid substrate was added beneath the radical system of each plant. In total, 20 plants were used for each of the three treatments (60 plants in total); this 60 pots were randomly located in the greenhouse. The plants were left to grow in a greenhouse for 17 weeks where the soil humidity was maintained similar to what would be found in the field; water was supplied each week; no fertilization was implemented. At the end of the experimental period, the following morphological and biomass traits were measured for all plants: root collar diameter, shoot length, root length, fresh shoot weight, fresh root weight, shoot dry weight and root dry weight. The formation of L. laccata 
mycorrhizae was confirmed in each of the inoculated plants using a stereomicroscope. Additiona1ly, based on the above-mentioned morphological and biomass traits, the plant Quality Index (QI) ${ }^{31}$ was calculated for the seedlings. The QI integrates several highly-correlated and non-correlated morphological growth traits, thus, giving a strong and objective proxy of young plant quality ${ }^{31}$.

\section{Statistical analysis.}

In order to test differences between the treatments of the inoculation experiment, a Tukey test was performed using the morphological traits measured ( $p$ value $<0.05$ ), using the $R$ function Tuke$\mathrm{yHSD}$ in $\mathrm{R}^{32}$.

\section{RESULTS}

\section{Vegetation pattern and mycorrhizal status.}

Forty-six vascular plant species were identified in the $N$. pumilio plot (Table 1). The understory vegetation was mainly composed of Chusquea montana Phil., Drimys andina (Reiche) R.A. Rodr. et Quez., Maytenus disticha (Hook) Urban, Berberis buxifolia Lam., Berberis serrate Lechler, Pernettya myrtilloides (Mirb) Blume, Pernettya pumila (L.f.) Hook and Ovidia andina (P.et E.) Meins. The herbaceous included Valeriana lapathifolia Vahl. and Viola reichei Skottsb.

Four different types of mycorrhizal associations were found for the 42 vascular plants species studied ( $91 \%$ of total vascular plant species). The AM associations were present in several life forms in a total of 33 vascular plant species (72\% of total vascular plant species). Two tree species (4\% of total vascular plant species) were associated with EM fungi; these included N. pumilio, which was the dominant tree in the plot with $85 \%$ of canopy cover and $N$. dombeyi, which was less frequent with $5 \%$ of canopy cover. Ericoid mycorrhizae were present in five plant species (11\%), orchid mycorrhizae were present in two species (4\%), and four plant species (9\%) were nonmycorrhizal (Aspleniaceae, Proteaceae, Polypodiaceae, and Cyperaceae). The ectomycorrhizal and ericoid plant species were phanerophytes, while the orchid type was associated with typical herbs (cryptophytes).

\section{Ectomycorrhizal fungi.}

Twenty-six EM fungi species were identified in the forest plot (Table 2); most of EM species were identified by sporocarps, except two putative morphotypes which belong to the family Corticiaceae. Cortinarius spp. were confirmed to be associated with $N$. pumilio via root-colonization analysis. Brown spored EM fungi genera (Cortinarius and Descolea) accounted for $62 \%$ of the total EM species richness, a characteristic pattern in Andean-Patagonian Nothofagus forests. Another EM genus that was found to associate with several plants in the plot was Laccaria, which was a genus composed of two species. Other EM fungal genera were represented by only one species (including Austropaxillus, Cenococcum, Gautieria, Inocybe, Russula, and Tricholoma).

\section{Inoculation experiment.}

We found that the inoculation of $N$. pumilio with the EM fungi Laccaria laccata showed a positive effect on seedling growth traits (Table 3). $N$. pumilio seedlings in natural soil inoculated with the fungus had clearly higher growth than the $N$. pumilio control seedlings in natural soil without inoculum (Table 3). Both aboveground and belowground traits were significantly affected by the fungal inoculum treatments. Plants grown in natural soils with the EM fungi inoculation (Table 3) also had significantly increased growth (Table $3)$. The quality index was significantly higher in the inoculated treatments when compared to the control (Table 3). 
Table 1. Vascular plant species present in the Nothofagus pumilio plot, with their respective family, life form and mycotrophic status.

\begin{tabular}{|c|c|c|}
\hline Species name & Family & $\begin{array}{l}\text { Life-form/Mycorrhizal } \\
\text { status }\end{array}$ \\
\hline Acaena antarctica $\mathrm{R}$. et $\mathrm{P}$. & Rosaceae & $\mathrm{Hem} / \mathrm{AM}$ \\
\hline Acaena ovalifolia $\mathrm{R}$. et P. & Rosaceae & Hem/AM \\
\hline Adenocaulon chilensis Less & Asteraceae & Hem/AM \\
\hline Asplenium dareoides A.N. Desv. & Aspleniaceae & $\mathrm{Phan} / \mathrm{NM}$ \\
\hline Berberis buxifolia Lam. & Berberidaceae & Phan/AM \\
\hline Berberis serrato-dentata Lechler & Berberidaceae & Phan/AM \\
\hline Blechnum chilense (Kaulf.) Mett. & Blechnaceae & Hem/AM \\
\hline Blechnum magellanicum (A.N. Desv.) Mett. & Blechnaceae & Hem/AM \\
\hline Blechnum penna-marina (Poir.) Kuhn. & Blechnaceae & Hem/AM \\
\hline Chusquea montana Phil & Poaceae & Phan/AM \\
\hline Codonorchis lessonii Lindl. & Orchidaceae & Cryp/OR \\
\hline Drimys andina (Reiche) R.A. Rodr. et G. Forster & Winteraceae & Phan/AM \\
\hline Embothrium coccineum J.R. et. G. Forster & Proteaceae & Phan/NM \\
\hline Empetrum rubrum Vahl ex Willd. & Ericaceae & $\mathrm{Phan} / \mathrm{ER}$ \\
\hline Escallonia alpina Poepp. ex. DC. & Escalloniaceae & Phan/AM \\
\hline Gaultheria phillyreifolia(Pers.) Sleumer & Ericaceae & Phan/ER \\
\hline Gavilea lutea (Pers.) Correa & Orchidaceae & Cryp/OR \\
\hline Grammitis magellanicaA.N. Desv. & Polypodiaceae & $\mathrm{Phan} / \mathrm{NM}$ \\
\hline Greigia landbekii (Lechler ex Phil) Phil ex F. Phil & Bromeliaceae & Hem/AM \\
\hline Gunnera magellanica Lam & Gunneraceae & Hem/AM \\
\hline Hymenophyllum secundum Hook et Grev. & Hymenophyllaceae & Phan/AM \\
\hline Lagenifera hirsuta (Poepp. ex Less) Dudley & Asteraceae & Hem/AM \\
\hline Lagenifera hariotti (Franchet) Dudley & Asteraceae & $\mathrm{Hem} / \mathrm{AM}$ \\
\hline Lycopodium magellanicum (P. Beauv) Sw. & Lycopodiaceae & Cham/AM \\
\hline Maytenus disticha (Hock. f.) Urban & Celastraceae & Phan/AM \\
\hline Myoschilos oblonga R. et. P. & Santalaceae & Hem/AM \\
\hline Myrceugenia chrysocarpa (Berg) Kausel & Myrtaceae & Phan/AM \\
\hline Nothofagus dombeyi (Mirb.) Oerst & Nothofagaceae & Phan/EM \\
\hline Nothofagus pumilio (P. et E.) Krasser & Nothofagaceae & Phan/EM \\
\hline Osmorhiza chilensis $\mathrm{H}$. et A. & Apiaceae & $\mathrm{Hem} / \mathrm{AM}$ \\
\hline Ovidia andina (P. et E.) Meisn. & Thymelaeaceae & Phan/AM \\
\hline Perezia pedicularifolia Less & Asteraceae & $\mathrm{Hem} / \mathrm{AM}$ \\
\hline Perezia prenanthioides Less & Asteraceae & Hem/AM \\
\hline Pernettya myrtilloides Zucc. ex Steud & Ericaceae & Phan/ER \\
\hline Pernettya poeppigii (D.C.) Klotzsch & Ericaceae & Phan/ER \\
\hline Pernettya pumila (L.f) Hook & Ericaceae & Phan/ER \\
\hline Ranunculus chilensis D.C. & Ranunculaceae & Hem/AM \\
\hline Ranunculus peduncularis J.E. Sm. & Ranunculaceae & Hem/AM \\
\hline Ribes cucullatum Hook. et Arn. & Grossulariaceae & Phan/AM \\
\hline
\end{tabular}




\begin{tabular}{lll} 
Ribes magellanicum Poir. & Grossulariaceae & Phan/AM \\
\hline Rubus geoides J.E. Sm. & Rosaceae & $\mathrm{Hem} / \mathrm{AM}$ \\
\hline Senecio acanthifolius Hombr. et Jacq. & Asteraceae & $\mathrm{Hem} / \mathrm{AM}$ \\
\hline Senecio trifurcatus (G. Forster) Less. & Asteraceae & $\mathrm{Hem} / \mathrm{AM}$ \\
\hline Uncinia brevicayulis (Thomars) Kunth. & Cyperaceae & $\mathrm{Hem} / \mathrm{NM}$ \\
\hline Valeriana lapathifolia Vahl. & Caprifoliaceae & $\mathrm{Hem} / \mathrm{AM}$ \\
\hline Viola reichi Skottsb. & Violaceae & $\mathrm{Hem} / \mathrm{AM}$
\end{tabular}

Life forms: Phan=phanerophytes, Cham=chamaephytes, $C$ ryp=cryptophytes,

Hem=hemicryptophytes. Mycorrhizal status: EM=ectomycorrhiza, AM=arbuscular mycorhiza, $\mathrm{ER}=$ ericoid, $\mathrm{OR}=$ orchid, $\mathrm{NM}=$ non mycorrhizal.

Table 2. Ectomycorrhizal (EM) fungi species identified in the Nothofagus pumilio plot.

\begin{tabular}{l}
\hline Species name \\
\hline Austropaxillus boletinoides (Singer) Bresinsky \& Jarosch (b) \\
\hline Cenococcum geophilum Fr. (b) \\
\hline Cortinarius albocanus (E. Horak \& M.M. Moser) Peintner \& M.M. Moser (b) \\
\hline Cortinarius austroacutus M.M. Moser (a) \\
\hline Cortinarius austrolimonius M.M. Moser \& E. Horak (a) \\
\hline Cortinarius austrosalor M.M. Moser (a) \\
\hline Cortinarius choloides E. Horak (a) \\
\hline Cortinarius clorophanus M.M. Moser (a) \\
\hline Cortinarius egenus E. Horak (a) \\
\hline Cortinarius flammuloides E. Horak \& M.M. Moser (a) \\
\hline Cortinarius fulvoconicus M.M. Moser (a) \\
\hline Cortinarius magellanicus Speg. (b) \\
\hline Cortinarius pachynemeus M.M. Moser (a) \\
\hline Cortinarius permagnificus E. Horak (a) \\
\hline Cortinarius pugionipes M.M. Moser (a) \\
\hline Cortinarius rubrobasalis M.M. Moser \& E. Horak (a) \\
\hline Cortinarius squamiger M.M. Moser (a) \\
\hline Descolea antarctica Singer (b) \\
\hline Gautieria inapire Palfner \& E. Horak (b) \\
\hline Inocybe bridgesiana Singer (a) \\
\hline Laccaria laccata (Scop.) Cooke (b) \\
\hline Laccaria ohiensis (Mont.) Singer (a) \\
\hline Russula fuegiana Singer (b) \\
\hline Tricholoma fusipes E. Horak (a) \\
\hline "Nothofagirhiza reticulosa" *Morphotype a aff. Corticiaceae (b) \\
\hline "Nothofagirhiza vinicolor" *Morphotypeb aff. Corticiaceae (b) \\
\hline
\end{tabular}

Identification by: (a)=(4); (b)=this study. "Nothofagirhiza reticulosa" described by Palfner (2001) $)^{5}$, "Nothofagirhiza vinicolor" described by Palfner \& Godoy (1996)². 
Table 3. Inoculation experiment, showing the growth effects of the ectomycorrhizal (EM) fungus Laccaria laccata in different morphological and biomass traits of Nothofagus pumilio seedlings.

\begin{tabular}{lllllllll}
\hline Treatment & $\begin{array}{l}\text { Root } \\
\text { collar } \\
\text { diameter } \\
(\mathrm{mm})\end{array}$ & $\begin{array}{l}\text { Shoot } \\
\text { length } \\
(\mathrm{cm})\end{array}$ & $\begin{array}{l}\text { Root } \\
\text { length } \\
(\mathrm{cm})\end{array}$ & $\begin{array}{l}\text { Shoot } \\
\text { fresh } \\
\text { weight }(\mathrm{g})\end{array}$ & $\begin{array}{l}\text { Root fresh } \\
\text { weight }(\mathrm{g})\end{array}$ & $\begin{array}{l}\text { Shoot dry } \\
\text { weight }(\mathrm{g})\end{array}$ & $\begin{array}{l}\text { Root dry } \\
\text { weight }(\mathrm{g})\end{array}$ & Q.I. \\
\hline Control & 0.20 & 8.1 & 11.4 & 0.50 & 0.24 & 0.12 & 0.11 & 0.47 \\
\hline $\begin{array}{l}\text { Natural soil } \\
+ \text { inoculum }\end{array}$ & $0.33^{*}$ & $10.1^{*}$ & $13.1^{*}$ & $0.71^{*}$ & $1.30^{*}$ & $0.22^{*}$ & $0.30^{*}$ & $0.53^{*}$ \\
\hline $\begin{array}{l}\text { Sterile soil } \\
+ \text { inoculum }\end{array}$ & $0.34^{*}$ & $13.1^{*}$ & $13.2^{*}$ & $1.33^{*}$ & $1.71^{*}$ & $0.47^{*}$ & $0.41^{*}$ & $1.04^{*}$ \\
\hline
\end{tabular}

Q.I.: Quality Index, resulting by combining the measured morphological traits, according to Ritchie $(1984)^{31}$. *denotes statically significant differences between the control and the treatments with fungal inoculum (Tukey test, $\mathrm{p}$ value $<0.05$ ).

\section{DISCUSSION}

The vascular flora found in the forest plot (Table 1) is typical of Chilean temperate rainforests located at the vegetation limit of the Andean treeline and was best classified as Drimys andina - Nothofagetum ${ }^{33}$. Other studies have documented that this forest differs in age and growth characteristics compared to lowland temperate rainforests, likely due to the effects of frequent natural disturbances $^{34,35}$; lowland $N$. pumilio forests tend to be older and taller than the forest described here. The vascular flora described here has varied mycorrhizal associations: Nothofagus species were found to be exclusively associated with EM fungi, while most other plant species (72\%) were dominated by AM fungi. Furthermore, ericoid mycorrhizae are typically associated with the families Empetraceae and Ericaceae. Additionally, orchid mycorrhizae were found in two Orchidaceae species. One species of the genus Gunnera, which is known to take part in a facultative tripartite association (AM fungi and the N-fixing cyanobacteria Nostoc punctiforme $e^{36}$ ), was also found in the plot (Table 1). Non-mycorrhizal plants included a representative of Cyperaceae, two species of epiphytic ferns (Aspleniaceae and Polypodiaceae), and one species of
Proteacaeae (non-mycorrhizal and which has preoteoid roots, a nutrient-uptake adaptation). In the region, all these families are typically considered non-mycorrhizal ${ }^{9,10,11}$.

Although the study of fungal diversity has been traditionally dependent on fruiting bodies, as in this study, there is an increasing necessity of comparing these results with those from molecular and metagenomic studies ${ }^{37,38}$. The Puyehue National Park, where this study took place, has been recently studied in terms of its AM fungal diversity $^{14,15}$, and in its whole soil fungal diversity ${ }^{7}$, including all fungal functional groups (EM, AM, saprophytic fungi, lichens, etc.). Although these mentioned metagenomic studies were not conducted on the exact plot as this study, we hope to give future insights for fungal diversity comparisons using traditional and modern taxonomic methods.

\section{Ectomycorrhizal fungi species and their ecosys- tem roles in $N$. pumilio forests.}

The diversity of agaricoid fungi recorded in Patagonian forests is comparable to similar temperate forest ecosystems in the Northern hemisphere ${ }^{6}(\mathrm{Ta}-$ ble 2). This result is in accordance with previous studies in the region ${ }^{1,2,3,4,5,6}$. Excluding Nothofa- 
gus spp., most of the vascular flora in the region is dominated by AM fungi ${ }^{8,9,10,11,12,13,14,15}$. There is not much certainty about species-specific associations between the ten Chilean Nothofagaceae species and their mycobionts; it is yet unknown even whether there are differences in the EM community structure of evergreen and deciduous forests. However, the results here provide some evidence that Southern Andean N. pumilio forests are distinct, not only based on EM species composition but also in terms of the morphology of the encountered fungal taxa. The dominance of Cortinarius spp. in association with $N$. pumilio was confirmed by this study. Cortinarius represented the 58\% (15 species) of the total EM fungal richness. Most registered EM fungal species are common in Nothofagus forests in Chile and in limitrophous zones that span a wide latitudinal and altitudinal range in Argentina $^{1,5,39}$. Examples of these common species are Austropaxillus boletinoides, Cortinarius flammuloides, C. magellanicus, Descolea antarctica, Laccaria laccata, Russsula fuegiana and Tricholoma fusipes.

The upper soil layers in the study area consists mainly of deposits of broad pyroclastic particles produced by repeated past volcanic eruptions. This material promotes rapid drainage of rainwater and snowmelt and, due to its dark color, heats up considerably when exposed to direct sunlight. Resulting water stress, which adds to highly variable temperatures during diurnal and annual cycles, would likely favor basidiomycete dominance, as these fungi form secotioid or hypogeous fruiting bodies (examples include Cortinarius albocanus and Gautieria inapire). As indicated by Moser \& Horak $(1975)^{16}$ and Horak \& Moser $(1965)^{40}$, the success of secotioid ectomycorrhizae under the mentioned conditions is evident by the high diversity of sequestrate Cortinarius species in Andean Patagonian Nothofagus forests.

An alternative response to soil water stress would be a retreat of the mycelia towards deeper and moister soil layers, and this would be correlated with the formation of fruiting bodies with long, radicating stipes during the rainy season. This is the exact pattern of Cortinarius pugionipes, which has been repeatedly observed at the study region; so far, C. pugionipes has been only observed in N. pumilio forests ${ }^{16}$ (according to Moser \& Horak (1975) and the present study) and may be a specific mycobiont of this tree species. Likewise, the unidentified ectomycorrhizal morphotypes (mostly dense mycelial mats under the leaf litter) are putative members (taxa) of the Corticiaceae: "Nothofagirhza vinicolor" and "Nothofagirhiza reticulata". These taxa so far have been found associated exclusively with $N$. pumilio. "N. vinicolor" is easy to detect in the field by the dark red color of its periferical mat-like mycelium and has been observed in several Andean N. pumilio forests and in the coastal mountains of south-central Chile ${ }^{5}$. So far "N. vinicolor" has not been found in association with any other Nothofagus species. Morphological methods should be complemented with molecular methods; sequencing soil samples from Argentinian Nothofagus forests, Marín et al, (2017a) ${ }^{7}$ and Nouhra et al, $(2013)^{41}$ found similar EM genera to those described in this study.

The only Ascomycete among the identified EM species is the cosmopolitan anamorphic species Cenococcum geophilum, member of the Gloniaceae family ${ }^{42}$. C. geophilum has been reported in a wide range of natural and managed forests and in greenhouse and nursery cultures ${ }^{3,5}$. It seems to be particularly common in soils periodically prone to water stress, which reflects the conditions of our study plot. The most interesting EM species found is probably the hypogeous basidiomycete Gautieria inapire. This species is so far only known from the type locality associated with N. pumilio $^{5,43}$, where it forms semihypogeous fruiting bodies in dense clusters. This is another striking example of functional adaptation to adverse environmental conditions, as the fruiting bodies emerge from 
dense mycelial mats directly beneath the soil surface. This results in moisture retention, improving conditions for the survival of primordia during late summer and early autumn before the rainy season starts. Another important role of the mentioned mycelial mats may be the formation of a nursery bed for tree seedling establishment and survival, as has been suggested by Griffiths et al $(1991)^{44}$ for the closely related northern hemisphere species Gautieria monticola.

The feedback between soil, mycorrhizae, and plants is especially important for plant growth at forest altitudinal limits ${ }^{45,46}$. In conservation programs, if certain plants and fungi are present, there is a considerable potential for $N$. pumilio seedling production and health (Table 3 ). This would have strong implications for a country, such as Chile, that is highly dependent on the forestry industry, where sustainable local production remains to be achieved.

\section{CONCLUSIONS}

Most of the vascular flora (91\%) in the pristine forest had mycorrhizal associations, de- monstrating the importance and prevalence of root symbionts in the ecology of forest ecosystems. This study should be considered as a baseline for further studies of mycorrhizal diversity and ecology in this particular forest ecosystem. Based on identification of fruiting bodies, we listed a total of 26 EM fungi species in the $N$. pumilio forest at the treeline of Puyehue National Park, Chile. However, molecular methods are definitely needed to further identify soil biota and to provide a complementary view of the diversity and functionality of this important component of the ecosystem. The inoculation assays with EM fungi showed a potential for using inoculations as a tool in restoration programs, especially in commonly disturbed (earthquakes, fires, volcanic events) areas of the region.

\section{ACKNOWLEDGEMENTS}

We thank Emily Giles for her helpful comments regarding this manuscript. Study in memory of Eduardo Valenzuela. This study was partially funded by the CONICYT National Doctorate Scholarship No. 21150047, and by the FONDECYT projects No. 1141060 and No. 3150175.

\section{REFERENCES}

1. Garrido N. Agaricales s. 1. und ihre Mykorrhizen in den Nothofagus-Wäldern Mittelchiles. Bibliotheca Mycologica 120. Berlin: Ed. J. Cramer; 1988. 528 p.

2. Palfner G, Godoy R. "Nothofagirhiza vinicolor" + Nothofagus pumilio (Poepp. et Endl.) Krasser. Descriptions of Ectomycorrhizae. 1996; 1:6570.

3. Flores R, Godoy R, Palfner G. Morfo-anatomía de la ectomicorriza Cenococcum geophilum Fr. en Nothofagus alessandrii Esp. Gayana Bot. 1997; 54(2):157-162.
4. Valenzuela E, Moreno G, Garnica S, Godoy R, Ramírez R. Mycosociology in native forests of Nothofagus of the X Región of Chile, diversity and ecological role. Mycotaxon. 1999; 72:217-226.

5. Palfner G. Taxonomische Studien an Ektomyk orrhizen aus den Nothofagus-Wäldern Mittelsüdchiles. Bibliotheca Mycologica 190. Berlin: Ed. J. Cramer; 2001. 243 p.

6. Palfner G. Diversity and community studies on Fagus/Nothofagus ectomicorrhizae from European and South American Forest. In: de Schrijver A, Kint V, Lust N, editors. Procceding of the 
Workshop Comparison of ecosystems functioning and biogeochemical cycles in temperate forests in Southern Chile and Flanders. Ghent: Academia Press; 2002. p. 119-129.

7. Marín C, Godoy R, Valenzuela E, Schloter M, Wubet T, Boy J, et al. Functional land-use change effects on soil fungal communities on Chilean temperate rainforests. J. Soil Sci. Plant Nutr. 2017a; 17(4):985-1002. Doi: http://dx.doi.org/10.4067/ S0718-95162017000400011

8. Godoy R, Mayr R. Caracterización morfológica de micorrizas vesículo-arbusculares en coníferas endémicas del sur de Chile. Bosque. 1989; 10(1-2):89-98. Doi: http://dx.doi.org/10.4206/bosque.1989.v10n1n2-10

9. Carrillo R, Godoy R, Peredo H. Simbiosis micorrízica en comunidades boscosas del valle Central en el Sur de Chile. Bosque. 1992; 13(2):5767. Doi: http://dx.doi.org/10.4206/bosque.1992. v13n2-08

10. Godoy R, Romero R, Carrillo R. Estatus micotrófico de la flora vascular en bosques de coníferas nativas. Rev. Chil. Hist. Nat. 1994; 67: 209220.

11. Fontenla S, Godoy R, Rosso P, Havrylenko M. Root associations in Austrocedrus forest and seasonal dynamics of arbuscular mycorrhizas. Mycorrhiza. 1998; 8(1):29-33. Doi: http://dx.doi. org/10.1007/s005720050207

12. Castillo CG, Borie F, Godoy R, Rubio R, Sieverding E. Diversity of mycorrhizal plant species and arbuscular mycorrhizal fungi in evergreen forest, deciduous forest and grassland ecosystems of Southern Chile. J. Appl. Bot. Food Qual. 2006; 80(1):40-47.

13. Oehl F, Castillo C, Schneider D, Säle V, Sie- verding E. Ambispora reticulata, a new species in the Glomeromycota from mountainous areas in Switzerland and Chile. J. Appl. Bot. Food Qual. 2012; 85(2):129-133.

14. Marín C, Aguilera P, Cornejo P, Godoy R, Oehl F, Palfner G, et al. Arbuscular mycorrhizal assemblages along contrasting Andean forests of southern Chile. J. Soil Sci. Plant Nutr. 2016; 16(4):916-929. Doi: http://dx.doi.org/10.4067/ S071895162016005000065

15. Marín C, Aguilera P, Oehl F, Godoy R. Factors affecting arbuscular mycorrhizal fungi of Chilean temperate rainforests. J. Soil Sci. Plant Nutr. 2017b; 17(4):966-984. Doi: http://dx.doi. org/10.4067/S0718-95162017000400010

16. Moser M, Horak E. Cortinarius Fr. und nahe verwandte Gattungen in Südamerika. Vaduz: Ed. J. Cramer; 1975. 744 p.

17. Garnica S, Weiss M, Oberwinkler F. New Cortinarius species from Nothofagus forests in South Chile. Mycologia. 2002; 94(1):136-145. Doi: http://dx.doi.org/10.2307/3761853

18. Palfner G. Tylopilus temucensis, sect. Oxydabiles (Fungi, Basidiomycota, Boletaceae), new species and first record of the genus from Southamerican Nothofagus forest. Fungal Div. 2005; 20:157-166.

19. Palfner G. Primer registro de Russula pectinatoides (Basidiomycota, Russulaceae) para Chile. Gayana Bot. 2011; 68(2):333-337. Doi: http:// dx.doi.org/10.4067/s071766432011000200025

20. Armesto JJ, Manuschevich D, Mora A, Smith-Ramirez C, Rozzi R, Abarzúa AM, Marquet PA. From the holocene to the Anthropocene: A historical framework for land cover change in southwestern South America in the past 
15,000 years. Land Use Policy. 2010; 27(2):148160. Doi: http://dx.doi.org/10.1016/j.landusepol.2009.07.006

21. Oyarzún CE, Godoy R, de Schrijver A, Staelens J, Lust N. Water chemistry and nutrient budgets in an undisturbed evergreen rainforest of southern Chile. Biogeochemistry. 2004; 71(1):107123. Doi: http://dx.doi.org/10.1007/s10533-0044107-x

22. Godoy R, Oyarzún C, Gerding V. Precipitation chemistry in deciduous and evergreen Nothofagus forest of southern Chile under a low-deposition climate. Basic Appl. Ecol. 2001; 2(1):65-72. Doi: http://dx.doi.org/10.1078/1439-1791-00037

23. Marticorena C, Quezada, M. Catálogo de la flora vascular de Chile. Gayana Bot. 1985; 42:5157.

24. Ellenberg H, Mueller-Dombois M. A Key to Raunkiaer plant life forms with revised subdivisions. Berichte des Geobotanischen Institutes der Eidgenoessischen Technischen Hochschule Stiftung Rübel. 1966; 37:56-73.

25. Brundrett M. Diversity and classification of mycorrhizal associations. Biol. Rev. 2004; 79(3):473-495. Doi: http://dx.doi.org/10.1017/ S1464793103006316

26. Agerer R. Anatomical characteristics of identified ectomycorrhizas: an attempt towards a natural classification. In: Varma AK, Hock B, editors. Mycorrhiza: structure, function, molecular biology and biotechnology. Berlin: Springer Berlin Heidelberg; 1995. p. 685-734.

27. Agerer R. Streuzersetzende Großpilze im Höglwald-Projekt: Reaktionen im vierten Jahr der Behandlung. In: Kreutzer K, Göttlein A, editors. Ökosystemforschung Höglwald, Beiträge zur
Auswirkung von saurer Beregnung und Kalkung in einem Fichtenbestand. Hamburg: Beih Forstwiss Cbl.; 1991. p. 99-103.

28. Agerer R. Zur Ökologie der Mykorrhizapilze, Bibliotheca Mycologica 97. Berlin: Ed. J. Cramer; 1985. $160 \mathrm{p}$.

29. Gamundi IJ, Horak, H. Hongos de los Bosques Andinos-Patagónicos. Buenos Aires: Vázquez Mazzini Editores; 1993. 144 p.

30. Marx DH, Ruehle JL, Kenney DS, Cordell CE, Riffle JW, Molina RJ, et al. Commercial vegetative inoculum of Pisolithus tinctorius and inoculation techniques for development of ectomycorrhizae on container-grown tree seedlings. Forest Sci. 1982; 28(2):373-400.

31. Ritchie GA. Assessing seedling quality. In: Duryea ML, Landis TD, editors. Forestry nursery manual: production of bareroot seedlings. The Hague: Springer Netherlands; 1984. p. 243-259.

32. $\mathbf{R}$ Development Core Team. R: A Language and Environment for Statistical Computing. Vienna: The R Foundation for Statistical Computing; 2015. Available online at http://www.R-project. org/

33. Flores Toro L, Hildebrand-Vogel R. Estudio fitosociológico de los bosques de Nothofagus pumilio (P. et E.) Krasser del centro sur de Chile. Anales del Museo de Historia Natural de Valparaíso. $2006 ; 25: 21-32$.

\section{4. Álvarez C, Veblen TT, Christie DA, Gonzá-} lez-Reyes A. Relationships between climate variability and radial growth of Nothofagus pumilio near altitudinal treeline in the Andes of northern Patagonia, Chile. Forest Ecol Management. 2015; 342:112-121. Doi: http://dx.doi.org/10.1016/j.foreco.2015.01.018 
35. Armesto JJ, Smith-Ramírez C, Carmona MR, Celis-Diez JL, Díaz IA, Gaxiola A, et al. Old-growth temperate rain forests of South America: Conservation, plant-animal interactions, and baseline biogeochemical processes. In: Wirth $\mathrm{C}$, Gleixner G, Heimann M, editors. Old-Growth Forests. Berlin: Springer Verlag; 2009 p. 367-390.

36. Guevara M, Armesto JJ, Carú R. Genetic diversity of Nostoc microsymbionts from Gunnera tinctoria revealed by PCR -STRR fingerprinting. Microb. Ecol. 2002; 44(2):127-136. Doi: http:// dx.doi.org/10.1007/s00248-002-1019-y

37. Bueno CG, Marín C, Silva-Flores P, Aguilera $\mathbf{P}$, Godoy $\mathbf{R}$. Think globally, research locally: contrasting patterns of mycorrhizal symbiosis in South America. New Phytol. 2017;215(4):13061309. Doi: https://doi.org/10.1111/nph.14709

38. Godoy R, Silva-Flores P, Aguilera P, Marín C. Microbial Interactions in the plant-soil continuum: Research results presented at the Workshop "Mycorrhizal Symbiosis in the Southern Cone of South America”. J Soil Sci Plant Nutr. 2017;17 (4): $1-3$.

39. Horak E. Agaricales y gasteromicetes secotioides. Flora Criptogámica de Tierra del Fuego, tomo XI, fascículo 6: Fungi, Basidiomycetes. Buenos Aires: FECYC; 1980. p. 3-6.

40. Horak E, Moser, M. Fungi Austroamericani XII. Studien zur Gattungen Thaxterogaster Singer. Nova Hedwigia. 1965; 10(1-2):211-241.
41. Nouhra E, Urcelay C, Longo S, Tedersoo L. Ectomycorrhizal fungal communities associated to Nothofagus species in northern Patagonia. Mycorrhiza. 2013; 23(6):487-496. Doi: http://dx.doi. org/10.1007/s00572-013-0490-2

42. Spatafora JW, Owensby CA, Douhan GW, Boehm EW, Schoch CL. Phylogenetic placement of the ectomycorrhizal genus Cenococcum in Gloniaceae (Dothideomycetes). Mycologia 2012; 104(3):758-765. Doi: https://doi.org/10.3852/11233

43. Palfner G, Horak E. Gautieria inapire sp. nov., a new hypogeous species from Nothofagus forest in southern Central Chile. Sydowia. 2001; 53:140-151.

44. Griffiths RP, Castellano MA, Caldwell BA. Hyphal mats formed by two ectomycorrhizal fungi and their association with Douglas-fir seedlings: a case study. Plant and Soil. 1991; 134(2):255-259. Doi: http://dx.doi.org/10.1007/bf00012043

45. Körner C. Alpine plant life. Functional Plant Ecology of High Mountain Ecosystems. Berlin: Springer; 2003. 344 p.

\section{Godoy R, Paulino L, Valenzuela E, Oyarzún} C, Huygens D, Boeckx P. Temperate ecosystems of Chile: characteristic biogeochemical cycles and disturbance regimes. In: Verhoest N, Boeckx P, Oyarzún C, Godoy R, editors. Ecological advances on Chilean temperate rainforests. Ghent: Academia Press; 2009. p. 31-40. 